\title{
Motivating Boys
}

\section{to Read}

\section{Guys Read, a Summer Library Reading Program for Boys}

\author{
DEBORAH R. DILLON, DAVID G. O'BBIEN, CASSANDRA SCHARBER, AND KRISTEN MICHOLS-BESEL
}

A 2013 National Endowment for the Arts (NEA) report, How a Nation Engages with Art, illustrates that voluntary "literary" reading rates of adults have fallen ${ }^{1}$ compared to an applauded rise in $2008 .^{2}$

Prior to these two reports, other NEA research showed a serious decline in both literary and book reading by adults of all ages, races, incomes, and education levels. ${ }^{3}$ Other survey data measuring what youth do in their leisure time indicated that young men and women read fewer than twelve minutes per day. ${ }^{4}$ These reports show that boys' frequency of reading lags behind that of girls and that boys are reading neither the number of books nor the range of genres they should read as they progress through the elementary grades.

Public libraries, armed with data on declining reading rates and continued academic achievement gaps between boys and girls, have tried to encourage programs that support young people in reading. This article illustrates Guys Read, one library system's program geared toward preteen and adolescent boys.

Created by children's author and former National Ambassador for Children's Literature Jon Scieszka, Guys Read is a web-based literacy program that strives to motivate boys to read by connecting them with materials they want to read, in ways they like to read (see www.guysread.com). Scieszka has these goals for Guys Read:

- Call attention to boys' literacy.

- Expand our definition of reading.

- Give boys choice.

- Encourage male role models.

- Be realistic. Start small.

- Spread the Guys Read word. ${ }^{5}$

Working in tandem with Scieszka, a Guys Read Summer Book Club program was designed by Hennepin County (MN) Library (HCL) in 2005. The goals of the initiative included encouraging boys to read more over the summer months and beyond, developing positive relationships between boys and male book club
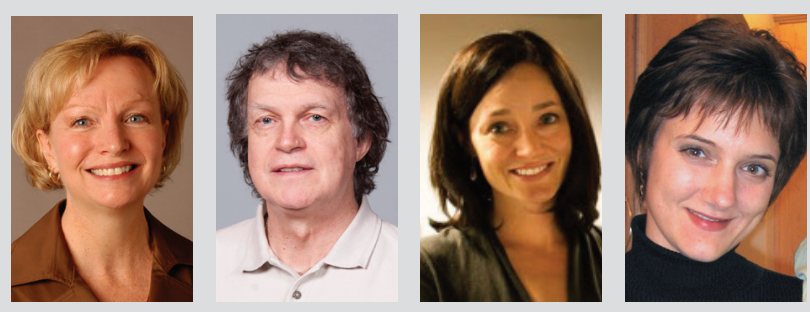

Deborah R. Dillon is Associate Dean for Graduate and Professional Programs, Professor of Literacy Education, and the Guy Bond Chair in Reading; David G. O'Brien is Professor of Literacy Education; and Cassandra Scharber is Associate Professor of Learning Technologies; all at the University of Minnesota. Kristen Nichols-Besel is Adjunct Professor of English Education, College Writing, and Multilingual Writing Support at Bethel University and Adjunct Professor in the Graduate Teaching Licensure Program at The College of St. Scholastica, Minnesota. 
facilitators, and fostering boys' positive attitudes and associations toward reading. ${ }^{6}$

\section{Objectives of the Study}

The purpose of this evaluation study was to document for HCL what clientele the program attracted; what the book clubs looked like in action; when and how the book clubs operated in particular settings; and the impact of the program on boys' attitudes, perspectives about themselves as readers, and reading practices. University researchers were asked to collaborate with the library staff to evaluate the effectiveness of the Guys Read Summer Book Club program. We hope the results of this evaluation study will help bring attention to the important work libraries do in fostering reading with young people, including boys; inform other libraries in their development of children's book clubs; and encourage rigorous evaluations of library programs. The following research questions guided the evaluation study:

1. What did the boys think about reading prior to and after participating in the Guys Read book clubs?

2. What are boys' perceptions about themselves as readers prior to and after participating in the book clubs?

3. What books/materials do boys read and what impact on reading habits and choices do the Guys Read clubs have?

4. What perceptions did the boys have of other males as readers prior to and after participating in the Guys Read book clubs and interacting with male book club leaders/mentors?

5. What activities and structures associated with the Guys Read book clubs helped the boys find reading meaningful and worthwhile?

6. What engaged boys and supported their reading and completion of books over the course of the book clubs?

\section{Perspectives and Theoretical Framework}

Work highlighting boys' and young men's reading often sets up dichotomies in which boys are compared to girls by overgeneralizing gendered identity and privileging certain forms and genres of reading in highlighting girls' advantages over boys.? Rowan et al. argue that researchers should focus on characteristics other than gender, such as socioeconomic status and class, that impact achievement. ${ }^{8}$ They call for an examination of diverse individuals and perspectives, including multiple subjectivities-acknowledging the many ways of being a boy, a girl, or, as Blackburn noted, "any other particular identity."

Rowan et al. also argue for broader conceptions of literacy, taking up the perspective of the New Literacy Studies (NLS), in which literacies are not singular but "embedded and situated within diverse institutional and cultural practices." ${ }^{10}$

Smith and Wilhelm focus on understanding the perspectives and experiences of boys as individuals because of the diversity of boys' perspectives on reading and on themselves as readers. These researchers found that boys see reading as a "schoolish activity." They advocate disassociating the experience of reading from its articulation in schools, including the genres read in school; and moving boys to spaces (such as libraries) in which they can take up reading, have choice in what they read, and form positive perceptions of themselves as readers. ${ }^{11}$

These theoretical perspectives that avoid essentializing gender and complicate literate practices as multiple, situated, and constitutive of and constituted by multiple identities were used to guide our research and interpretation of findings.

\section{Participants, Methods, Data Sources, and Analysis Tools}

Designed for boys to join together with other boys in small groups (ten to twenty boys per group) to read books and discuss them, sixteen Guys Read summer book clubs were studied between June and August 2006. The boys who participated in these clubs were primarily readers. Individual clubs met between three and six times over the course of the summer. Data were collected as a naturally occurring part of the program in three stages that moved from macro- to micro-levels of investigation, which are described next.

\section{Stage One}

We gathered data from 76 of the 194 participants (39 percent) across the sixteen clubs using an online pre- and post-survey. Survey respondents from the study were predominantly white males (84 percent) with some males of color (4 percent Native American, 3 percent Asian, 3 percent African American) from fourth to ninth grade. The survey included thirty-two items, some choice and some open-ended. It assessed boys' reading attitudes and habits, perspectives and roles of gender and reading, perceptions about ability and self-efficacy as readers, and perceptions about the Guys Read program. These data were analyzed using both descriptive statistics and qualitative analysis.

The research team also gathered pre- and post-program focus group data at the initial and final meetings of the discussion groups. A focus group interview guide with structured questions prompted fifteen- to twenty-minute discussions among the group members from twelve of the sixteen clubs. The purpose of the focus group sessions was to enable boys to elaborate on their survey responses. These sessions were audio-recorded and transcribed; the transcripts were analyzed using a question-by-question analysis to generate patterns of responses. ${ }^{12}$ Twelve book clubs completed both pre- and post-program 
focus group interviews. Fifteen total pre-program focus group interviews and thirteen total post-program focus group interviews were conducted.

\section{Stage Two}

Across the sixteen library sites that held Guys Read clubs, we selected seven to observe across the summer of 2006. We observed each of the selected clubs two or more times across the program (beginning, middle, and end) for a total of twentytwo meeting observations. The clubs were observed as follows: Club A: 5 times; Club B: 4 times; Club C: 3 times; Club D: 3 times; Club E: 3 times; Club F: 2 times; Club G: 2 times. To ensure that field notes were complete and focused, a structured observation guide was used by evaluators to record data. Data were analyzed using constant comparative analysis. ${ }^{13}$

\section{Stage Three}

The research team interviewed eleven boys individually and seven in small groups from across the sixteen clubs. We used purposive sampling to select the boys according to these criteria: one or two boys from each of the seven clubs observed; boys who represented a range of perspectives about reading and participating in the program; and boys who seemed open and interested in articulating their ideas. ${ }^{14}$

Our goal was to glean additional data about the boys' individual perceptions about reading and their experiences in the clubs. The interviews were audio-recorded and transcribed. The transcripts were analyzed using a within- and cross-case analysis of responses to questions; case study write-ups were constructed for each interviewee..$^{15}$

\section{Overall Results}

Pre-survey data indicated that the boys who participated in the Guys Read program initially chose to do so because their parents wanted them to (46 percent); they wanted to be with friends (39 percent); they wanted to participate in an organized activity over the summer (39 percent); they wanted to read some books they wanted to read (32 percent); and they wanted to discuss books so they could understand them better (32 percent).

Before the program, the participants viewed girls as more frequent readers than boys because of a perception that girls have more time to read; participants noted specifically that girls are less involved in sports or in playing video games. However, the post-surveys showed that the boys tended to believe that the two genders read about the same amount. The post-survey asked the boys if the Guys Read program helped them become better readers; 67 percent selected "yes" and explained that they were reading more books and discussing them. The boys also indicated that they believe they will read more in the future because of the Guys Read program (69 percent) because they learned about and read good books, the reading and discussion "inspired them," and they believed the more you read the better you become at reading.

Finally, the boys noted in the post-survey that the benefits of participating in the Guys Read program included the opportunity to read more books, to "get better at reading," and to have fun.

Observations of book club sessions elucidated a juxtaposition of academic (school-like) space and social/club space (eating, joking, and jostling). The actions observed within the fortyfive-minute book club sessions confirmed the boys' perceptions that the program was fun. Most boys came to the session prepared and willing to participate in the discussion. Focus group and individual interview comments provided more specific responses or elaborated on the constructs assessed in the survey.

\section{Results Organized by Research Questions}

\section{Research Question \#1}

What do boys think about reading prior to, and after participating in the Guys Read book clubs? In response to the question, How much do you enjoy reading?, on the pre-survey boys indicated that reading was one of their favorite activities (70 percent said "I like reading") while others commented that they read if there is nothing else to do (29 percent). Overall, the data indicated that boys participating in Guys Read selected the book club because reading is something they like to do. For example, of the boys who signed up:

- 47 percent read print materials four or more hours a week.

- 22 percent read digital text four or more hours a week.

- 25 percent read for homework four or more hours per week.

- All read print.

- None indicated that they do not read.

About 40 percent of the club members reported that they had participated in previous book clubs. Most of the respondents reported a balance of activities they engaged in when not reading -in order of preference: spending time with friends (15 percent); playing sports (12 percent); playing video games (15 percent). Few reported watching television in their spare time. After participating in the book clubs, when asked which reasons influence their desire to read, a higher percentage of boys indicated that they like to read what friends are reading (33 percent). 
Table 1. Results to the question, "How well do you think you read in comparison to other people your age?"

\begin{tabular}{|l|c|c|c|c|c|c|c|}
\hline & \multicolumn{2}{|c|}{ Very Well } & \multicolumn{2}{c|}{ Better than Average } & \multicolumn{2}{|c|}{ About Average } & \multicolumn{2}{c|}{ Not as Well } \\
\hline $\begin{array}{l}\text { Pre-survey } \\
(\boldsymbol{n}=\mathbf{7 6})\end{array}$ & 36 & 47 percent & 21 & 28 percent & 14 & 18 percent & 5 percent \\
\hline $\begin{array}{l}\text { Post-survey } \\
(\boldsymbol{n}=\mathbf{3 6})\end{array}$ & 11 & 31 percent & 10 & 28 percent & 10 & 28 percent & 5 \\
\hline
\end{tabular}

Table 2. Results to the question, "How do you know how well you read in comparison to other people your age?"

\begin{tabular}{|l|c|c|c|c|c|c|c|}
\hline & \multicolumn{2}{|c|}{ Test Results Show Me } & \multicolumn{2}{|c|}{ My Reading in School } & \multicolumn{2}{|c|}{ My Parents } & \multicolumn{2}{c|}{ My Friends } \\
\hline $\begin{array}{l}\text { Pre-survey } \\
(\boldsymbol{n}=\mathbf{7 6})\end{array}$ & 38 & 50 percent & 20 & 26 percent & 13 & 17 percent & 5 \\
\hline $\begin{array}{l}\text { Post-survey } \\
(\boldsymbol{n}=\mathbf{3 6})\end{array}$ & 15 & 42 percent & 9 & 25 percent & 8 & 22 percent & 4 \\
\hline
\end{tabular}

\section{Research Question \#2}

What are boys' perceptions about themselves as readers prior to and after participating in the Guys Read clubs? Before the clubs started, boys were asked to assess their reading skills as well as how they knew about their reading skills. (See tables 1 and 2.)

In line with results for the first research question, the boys generally believed themselves to be competent readers when coming into the clubs. Additionally, the book clubs had little impact on how participants defined their reading competence, with the impact of how reading is evaluated in school, by parents, or based on test results being most important.

\section{Research Question \#3}

What books/materials do boys read and what impact on reading habits and choices do the Guys Read clubs have? In both the pre- and post-survey responses, the participants indicated that they read books about topics they are interested in. In the pre-survey, boys noted that they rely on recommendations from librarians for help in selecting books; but in the post-survey there was a shift, with the boys stating that they read what their friends are reading. This trend away from traditional book selection avenues (libraries and librarian recommendations) to peers may indicate the influence of the social nature of the book clubs on book choices. For book types, the boys indicated that they like books in a series (67 percent), fantasy books (59 percent), and comic books ( 45 percent). They stated that they were not fond of poetry (75 percent), graphic novels (46 percent), or history (41 percent).

\section{Research Question \#4}

What perceptions do boys have of other males as readers prior to and after participating in the Guys Read book clubs and interacting with male book club leaders/mentors? The boys' pre-survey responses indicated that these boys believed girls read more than boys do. Reasons given for this response included the boys' belief that girls have more time: "Girls, because I think that they might not do as many activities as boys;" that "Girls are more academic;" and boys reporting seeing girls read: "because I see girls reading a lot in the library and other places.”

A few boys indicated that boys and girls read the same or that boys read more than girls, but the post-survey responses included a greater number of boys stating that they read as much as or more than girls: "I think they read about the same;" "Boys like to read a lot too;" "Boys read more, or the same as girls."

\section{Research Questions \#5 and \#仍}

What activities and structures associated with the Guys Read book clubs help boys find reading meaningful and worthwhile? What engages boys and supports their reading and completion of books over the course of the book clubs? Utilizing the qualitative data that was compiled from the observations of the book clubs, the research team noted several trends. The structure of the book clubs ranged from very structured to non-existent. There were a wide variety of book club activities, including boys pulling questions for book conversation from a bucket, planned activities focused around the book, and game playing. One important aspect of the book clubs was that refreshments were available.

The books read by the boys were predetermined by facilitators or librarians prior to book clubs' first meetings (see table 3).

The following excerpts from field note data provide descriptions of the book club sessions at two sites and indicate the similarity yet variety of activities and interactions that occurred.

\section{Observation of Club A}

[prior]: Boys socialized, ate snacks.

[Ten min.]: Facilitator-led questions about book.

[Ten min.]: Author's website projected onto wall using LCD projector. Low lights. Facilitator and boys surf the site; took online "quiz" about book; told jokes. 


\begin{tabular}{|l|l|l|l|}
\hline $\begin{array}{l}\text { The Lost Years of Merlin* } \\
\text { Barron (1996) }\end{array}$ & $\begin{array}{l}\text { The Conch Bearer } \\
\text { Divakaruni (2005) }\end{array}$ & $\begin{array}{l}\text { Chasing the Falconers } \\
\text { Korman (2005) }\end{array}$ & $\begin{array}{l}\text { The Last Book in the Universe } \\
\text { Phillbrick (2002) }\end{array}$ \\
\hline $\begin{array}{l}\text { The Wizard Test } \\
\text { Bell (2006) }\end{array}$ & $\begin{array}{l}\text { Honus and Me } \\
\text { Gutman (1998) }\end{array}$ & $\begin{array}{l}\text { Midnight for Charlie Bone } \\
\text { Nimmo (2002) }\end{array}$ & $\begin{array}{l}\text { Truckers } \\
\text { Pratchett (2004) }\end{array}$ \\
\hline $\begin{array}{l}\text { Gregor the Overlander } \\
\text { Collins (2004) }\end{array}$ & $\begin{array}{l}\text { Among the Hidden* } \\
\text { Haddix (2000) }\end{array}$ & $\begin{array}{l}\text { Colder than Ice } \\
\text { Patneaude (2005) }\end{array}$ & $\begin{array}{l}\text { Chew on This } \\
\text { Wilson \& Schlosser (2006) }\end{array}$ \\
\hline $\begin{array}{l}\text { Gregor and the Prophecy of Bane } \\
\text { Collins (2005) }\end{array}$ & $\begin{array}{l}\text { The Devil and His Boy } \\
\text { Horowitz (2004) }\end{array}$ & $\begin{array}{l}\text { How Angel Peterson Got His Name } \\
\text { Paulsen (2004) }\end{array}$ & $\begin{array}{l}\text { The Gadget } \\
\text { Zindel (2003) }\end{array}$ \\
\hline
\end{tabular}

* Series books (indicated favorites of the boys)

[Eight min.]: Discussion of mythology (related to text); map of constellations on wall; boys out of chairs pointing to constellations.

[Eight min.]: Facilitator illustrated (using projector) how to use library's catalogue to find more books in series.

[Ten min.]: Closing; tickler to get boys interested in book for next meeting; Guys Read clubs during school year promoted; high fives as boys leave.

\section{Observation of Club E}

[Seventeen min.]: Boys trickled in and gathered at snack table; found a place to sit.

[Forty-eight min.]: Book discussion. Facilitator passed around a bucket of questions created by librarian and facilitator. Boys drew questions out of bucket and took turns answering.

[Five min.]: Drawing for prizes; introduced book for next meeting; parents arrived; boys left.

Observations of book club sessions confirmed that reading was taken up as a social activity instead of an academic one. Included within the forty-five-minute sessions was social time, eating refreshments, jostling and joking, and small-group discussion time. These actions confirmed that the boys perceived the program as fun. Most boys came to the sessions prepared and willing to participate in the discussion. Questions discussed often included whether the boys liked the books and how they would react to certain situations presented in the books; boys could participate in most of the discussions even if they had not read the books. The overall depth of the discussion and the ability of the leader to sustain the discussion varied widely across sites and may be a function of the experience and comfort level of the facilitator.

Conversations with boys via interviews and focus groups revealed the importance boys placed on having fun and being exposed to books that they wanted to read. The following are quotes reflecting the boys' perceptions of the book clubs:

- "I thought that it [the book club] was going to be one of those boring things that some other libraries have, but this one was a lot more fun."
- "It [the book club] has helped me read better. I found some good books. I found some new stuff, like authors and types of books. I found that they have all the good books in the teen section."

- "Reading is more fun in a book club, definitely." "Yah, much funner."

- "After we finished discussing the book, we got to eat a snack, and we got to run around the room."

When the boys were asked What was the best thing about the book club?, they primarily mentioned enjoying discussions: "Talking to other kids about how they feel about books" and finding new books to read: "Reading the books. I liked the books they picked out.” Boys also mentioned the importance of finding new books to read when they were asked about the biggest benefit of being in the book club: "I think the biggest benefit was realizing that there was more books than what I have read out there, and books that could be more interesting, new books." Mention of finding new books exceeded mention of food, but food was also a benefit of the book club: "The food, because I need food and I'm a growing man."

The benefit of finding new books to read appears in boys' responses to the question How have you changed [as a reader]? Two boys' comments represent the types of answers given: "I'm reading more. Every time I go to a library I pick up five books, and then I read them. So I think I read a lot more;" and "I'm reading more books, and I'm reading more fun books that I like. Before I was in book club I wasn't really reading books that I liked, I was only reading what I had to read."

Finally, when boys were asked If you could change anything about the book club, what would you change?, overwhelmingly their responses focused on wanting the book club to last longer and wanting to read more books: "Make it longer so we can read more books. I think we should read more than three books;" "I wish it would last about ten million times longer."

\section{Conclusions}

The research team was able to gather substantial and rich interview, focus group, and book club observation data, but the survey participation was an issue for this evaluation study. Boys' participation in evaluation activities was enhanced when 
librarians and facilitators were able to encourage participants during the clubs to fill out the online survey.

This research provided the library system with valuable information and data regarding the impact its Guys Read program had on the boys who attended these summer book clubs. Boys reported that they read more after participating in Guys Read. The results enabled HCL to use this data internally as well as with its funders in order to enhance program offerings; improve clubs so that they are responsive to HCL's diverse communities; and procure continued and additional funding to support its Guys Read program.

More widely, the results of this study highlight how Guys Read book clubs can be positive, safe spaces for boys to be readers, a model from which other libraries can work in attending to their younger, male constituents and their parents and guardians, thereby helping encourage a life-long love of reading.

\section{Update}

Since the first evaluation in 2006, we continued to work with HCL through the summer of 2008, at which point HCL had more than doubled the number of Guys Read book clubs it offered during the summer. Scieszka's Guys Read program continues to offer support for boys' reading as evidenced by Scieszka's website, including his map of available Guys Read clubs (www.guysread.com/more/maps). Seventeen HCL libraries offered Guys Read book clubs in summer 2016. ${ }^{16}$

In addition to their Guys Read book clubs, HCL also offers mixed-gender book clubs and genre-based mixed-gender book clubs. ${ }^{17}$ As Lauren Kewley, communication project coordinator at HCL, explained, "At HCL, Guys Read was a point-intime model based on a national movement, with a focus on high-interest books, and interactive and social discussions. We learned a lot from that model and have continued to apply that to our book clubs for kids. Increasingly, we're offering genreand interest-based book clubs, rather than gender-based. The goal of these book clubs continues to be supporting readers and engaging kids in summer learning." ${ }^{18} \&$.

\section{References}

1. National Endowment for the Arts, How a Nation Engages with Art (Research Report \#57) (Washington, DC: National Endowment for the Arts, 2013), 24.
2. National Endowment for the Arts, Reading on the Rise: A New Chapter in American Literacy (Washington, DC: National Endowment for the Arts, 2009).

3. National Endowment for the Arts, Reading at Risk: A Survey of Literary Reading in America (Research Division Report \#46) (Washington, DC: Office of Research and Analysis, 2004); National Endowment for the Arts, To Read or Not to Read: A Question of National Consequence (Research Report \#47) (Washington, DC: Office of Research and Analysis, 2007).

4. Bureau of Labor Statistics, "Average Hours Spent per Day in Leisure and Sports Activities, by Youngest and Oldest Populations," American Time-Use Survey (Washington, DC: US Department of Labor, 2016), https://www.bls.gov /tus/charts/leisure.htm.

5. Jon Scieszka, "About," Guys Read, accessed October 26, 2016, www.guysread.com/about.

6. Director of Summer Literacy Initiatives of HCL, e-mail message, June 2006.

7. Nola Alloway, "Swimming Against the Tide: Boys, Literacies, and Schooling-An Australian Story," Canadian Journal of Education 30, no. 2 (2007): 582-605; Mollie V. Blackburn, "Boys and Literacies: What Difference Does Gender Make?," Reading Research Quarterly 38, no. 2 (2003): 276-87; Wayne Martino, "Boys, Masculinities, and Literacy: Addressing the Issues," Australian Journal of Language and Literacy 26, no. 3 (2003): 9-27; Michael W. Smith and Jeffrey D. Wilhelm, "Reading Don't Fix No Chevys": Literacy in the Lives of Young Men (Portsmouth, NH: Heinemann, 2002).

8. Leonie Rowan et al., Boys, Literacies and Schooling: The Dangerous Territories of Gender-Based Literacy Reform (Buckingham, England: Open University Press, 2002).

9. Blackburn, "Boys and Literacies," 283.

10. Rowan et al., Boys, Literacies and Schooling, 92.

11. Smith and Wilhelm, "Reading Don't Fix No Chevys."

12. Michael Quinn Patton, Qualitative Research and Evaluation Methods, 3rd edition (Thousand Oaks, CA: Sage, 2001).

13. Anselm Strauss and Juliet Corbin, Basics of Qualitative Research: Grounded Theory Procedures and Techniques (Newbury Park, CA: Sage, 1990).

14. Patton, Qualitative Research and Evaluation Methods.

15. Ibid.

16. Lauren Kewley, communication project coordinator at Hennepin County (MN) Library, e-mail message, October 2016.

17. Ibid.

18. Ibid. 